\title{
QUES, a new Phaseolus vulgaris genotype resistant to common bean weevils, contains the Arcelin-8 allele coding for new lectin-related variants
}

\author{
Isabelle Zaugg • Chiara Magni · Dario Panzeri • \\ Maria Gloria Daminati • Roberto Bollini • \\ Betty Benrey • Sven Bacher · Francesca Sparvoli
}

\begin{abstract}
In common bean (Phaseolus vulgaris L.), the most abundant seed proteins are the storage protein phaseolin and the family of closely related APA proteins (arcelin, phytohemagglutinin and $\alpha$-amylase inhibitor). High variation in APA protein composition has been described and the presence of arcelin (Arc) has been associated with bean resistance against two bruchid beetles, the bean weevil (Acanthoscelides obtectus Say) and the Mexican bean weevil (Zabrotes subfasciatus Bohemian). So far, seven Arc variants have been identified, all in wild accessions, however, only those containing Arc-4 were reported to be resistant to both species. Although many efforts have been made, a successful breeding of this genetic trait into cultivated genotypes has not yet been achieved. Here, we describe a newly collected wild accession (named QUES) and demonstrate its resistance to both A. obtectus and Z. subfasciatus. Immunological and
\end{abstract}

I. Zaugg $\cdot$ S. Bacher

Unit of Ecology and Evolution, Department of Biology,

University of Fribourg, Fribourg, Switzerland

\section{Magni}

Department of AgriFood Molecular Sciences,

State University of Milan, Milan, Italy

D. Panzeri · M. G. Daminati · R. Bollini · F. Sparvoli ( $\square)$

Institute of Agricultural Biology and Biotechnology,

CNR, Via Bassini 15, 20133 Milan, Italy

e-mail: sparvoli@ibba.cnr.it

B. Benrey

LEAE, Institute de Zoologie, University of Neuchâtel,

Neuchâtel, Switzerland proteomic analyses of QUES seed protein composition indicated the presence of new Arc and arcelin-like (ARL) polypeptides of about 30 and $27 \mathrm{kDa}$, respectively. Sequencing of cDNAs coding for QUES APA proteins confirmed that this accession contains new APA variants, here referred to as Arc-8 and ARL-8. Moreover, bioinformatic analysis showed the two proteins are closely related to APA components present in the G12949 wild bean accession, which contains the Arc-4 variant. The presence of these new APA components, combined with the observations that they are poorly digested and remain very abundant in A. obtectus feces, so-called frass, suggest that the QUES APA locus is involved in the bruchid resistance. Moreover, molecular analysis indicated a lower complexity of the locus compared to that of G12949, suggesting that QUES should be considered a valuable source of resistance for further breeding purposes.

\begin{tabular}{ll}
\multicolumn{2}{l}{ Abbreviations } \\
$\alpha$ AI & $\alpha$-Amylase inhibitor \\
AIL & $\alpha$-Amylase inhibitor like \\
APA & $\begin{array}{l}\text { Arcelin/phytohemagglutinin/ } \alpha \text {-amylase } \\
\text { inhibitor }\end{array}$ \\
Arc & Arcelin \\
ARL & Arcelin-like \\
2DE & Two-dimensional gel electrophoresis \\
LC-MS/MS & Liquid-chromatography tandem mass \\
& spectrometry \\
PHA & Phytohemagglutinin \\
IS & Index of susceptibility
\end{tabular}

\section{Introduction}

Common bean, Phaseolus vulgaris L., is an important source for dietary protein in many countries, especially in 
the developing world. Each year, large amounts of the harvest are lost due to the bruchid beetle family (Coleoptera: Bruchidae). The main pests of stored beans are the bean weevil Acanthoscelides obtectus and the Mexican bean weevil Zabrotes subfasciatus (Cardona 2004). Some wild Mexican bean accessions have shown resistance against these weevils (Schoonhoven et al. 1983). The resistance has been associated with the presence of a particular class of seed proteins, the arcelins, which are components of a multigene family encoded by the $A P A$ locus [arcelin (Arc)/phytohemagglutinin (PHA)/ $\alpha$-amylase inhibitor ( $\alpha \mathrm{AI})$ ] (Osborn et al. 1988). Besides Arc, whose presence is restricted to only a few wild Mexican accessions, bean seeds contain other proteins encoded by the $A P A$ locus, the most abundant being PHA and aAI. The former is a lectin, which binds to carbohydrates and is toxic to mammals and birds, while $\alpha \mathrm{AI}$ inhibits the $\alpha$-amylase in the digestive tract of mammals and some coleopteran species; however, neither PHA nor $\alpha$ AI can effectively protect seeds from the attack of bean weevils (Santino et al. 1993; Nishizawa et al. 2007).

Lectins and lectin-related genes can be found in different Phaseolus species (Lioi et al. 2007). The APA gene family has evolved from a common ancestor through gene duplication and functional divergence, and shows a high degree of variation in number and abundance of its components (Mirkov et al. 1994; Sparvoli et al. 2001; Lioi et al. 2007). A gene coding for a lectin sequence underwent paralogous duplication which gave rise to the progenitor of the true lectin and the progenitor of lectin-related genes. In $P$. vulgaris, the lectin-related genes further evolved into $\alpha \mathrm{AI}$ and in some Mexican wild bean genotypes, they underwent a second duplication event giving rise to all Arc genes (Sparvoli et al. 2001; Lioi et al. 2003). Seven different variants of Arc (Arc-1 to Arc-7) have been found so far and can be clustered in three groups (Lioi et al. 2003). The most ancient cluster contains Arc-3 and Arc-4 and it seems to be the progenitor of two other subgroups; one with Arc-5 and Arc-7 and the other including Arc-1, Arc-2 and Arc-6 (Lioi et al. 2003). Studies on the molecular nature of the APA locus of Arc containing wild accessions indicate that it contains many duplications of lectin-related genes (Lioi et al. 2003). In addition, data on the sequence of a part of the APA locus from accession G02771, which accumulates Arc-5, confirmed these findings and showed the presence of traces of retrotransposon activities (Kami et al. 2006).

Arcelin is effective in resistance to bruchid beetles, especially Z. subfasciatus and to a lesser extent A. obtectus (Schoonhoven et al. 1983; Santino et al. 1993). It causes sub-lethal effects, which lead to prolonged larval developmental time and reduced adult weight (Osborn et al. 1988; Minney et al. 1990; Velten et al. 2007). Wild
P. vulgaris accessions containing Arc-5 and Arc-1 showed the highest resistance to Z. subfasciatus, followed by Arc$4>$ Arc-2 > Arc-3 (Cardona et al. 1990). However, only Arc-4 confers resistance to both bruchid species. The mechanism of toxicity of Arc to insects is unclear (Carlini and Grossi-de-Sá 2002). Some studies suggest that the insecticidal activity of Arc is due to a disruption of epithelial cells in the gut, while other authors propose that Arc might provide the insects with a source of poorly digestible protein (Minney et al. 1990; Paes et al. 2000). Moreover, it is not clear whether the same mechanism is working against the two bruchid species.

Different attempts have been made to breed resistance traits of wild common beans into cultivars and some successful breeding examples that exist (Cardona et al. 1990; Cardona and Kornegay 1999; Myers et al. 2001; Cardona 2004). However, to our knowledge, currently there are no commercial beans with proven resistance to bruchid beetles available, although a study reports the transfer of the resistance trait from a genotype of tepary bean $(P$. acutifolius) into an African bean cultivar (Mbogo et al. 2009; Kusolwa and Myers 2011). Problems in breeding include the loss of resistance traits in progeny or susceptibility to fungi or other diseases of breeding lines with bruchid resistance and it has been suggested that other factor (or factors) encoded by a gene linked to the arcelin locus might be important in such resistance (Kornegay and Cardona 1991; Cardona 2004; Nishizawa et al. 2007). Other constraints preventing successful breeding are the lack of understanding the mechanism of resistance and the organisation of the APA locus (Blair et al. 2010). In particular, Arc-4 containing accessions have a very complex APA locus, since all the APA components (Arc, PHA and $\alpha \mathrm{AI}$ ) are present in this variant. The molecular organisation of the Arc-4 APA locus has been well described in the G12949 accession, in which the presence of many other lectin-related genes has been reported. Data from the analysis of BAC clones covering the entire APA locus indicate a size of $\sim 500 \mathrm{kbp}$ (Galasso et al. 2005; Sparvoli et al. 2008; Gepts et al. 2008). On the basis of these data, it cannot be excluded that the Arc-4 APA locus undergoes recombination during the breeding process causing the loss of resistant components. However, research on this point has never been addressed.

In the frame of a study aimed at testing the resistance of different wild bean seeds to the bean weevil A. obtectus and the Mexican bean weevil Z. subfasciatus, we selected seeds of putative resistant bean populations collected in Mexico (Zaugg and Bacher, personal communication). Here, we describe in detail one of these genotypes, named QUES, and provide evidence of its resistance to larvae of both bruchids. We show that QUES seeds accumulate new APA variants, Arc- 8 and ARL- 8 and that they are devoid of 
aAI. Moreover, molecular analysis indicates a lower complexity of the QUES APA locus compared to that of the resistant genotype G12949, suggesting that QUES could represent a more promising candidate for breeding the resistance trait into cultivated bean. Finally, we also provide data showing that Arc- 8 and ARL- 8 are very abundant in A. obtectus feces, so-called frass, i.e. the fine powdery material that insect larvae pass as waste after digesting seeds. This finding indicates they are poorly digested by developing weevils and further supports their protective role as defence proteins.

\section{Materials and methods}

Plant materials

Seeds of 26 wild bean populations were collected at different locations in Mexico from November 2009 to January 2010 (Zaugg and Bacher, personal communication) (Table 1S); wild P. vulgaris accessions G12949 and G6388 were obtained from the Centro International de Agricultura Tropical, Cali, Colombia (CIAT). Of the 26 wild bean populations, three were selected for further testing (ISA, QUES, COPSPVC1). Preliminary trials have shown that ISA and QUES inhibit bruchid larval development, whereas COPSPVC1 was susceptible to bruchid attacks.

Insect performance

Bruchid beetles (A. obtectus and Z. subfasciatus) originated from insects collected in Mexico and were raised for several generations on cultivated $P$. vulgaris seeds. All experiments were carried out at $27{ }^{\circ} \mathrm{C}$ and $70 \%$ R.H. $( \pm 5 \%)$ in climate chambers at the Unit of Ecology and Evolution, Department of Biology, University of Fribourg, Fribourg, Switzerland.

For each bean genotype, 20 undamaged seeds of similar size and colour were chosen, weighed and filled in small plastic containers $(2.5-\mathrm{cm}$ diameter, $3-\mathrm{cm}$ height). We conducted five replicates for each genotype and beetle species in a completely randomized design. A. obtectus eggs were obtained by sieving beans on which newly emerged females had deposited eggs for 1 day. In each container, 40 eggs were singly transferred onto bean seeds using a moist brush. Care was taken that eggs remained undamaged during the treatment. Zabrotes subfasciatus females stick their transparent eggs onto seeds; therefore, experimental control over the exact number of eggs was limited in this species. Here, we added five $Z$. subfasciatus females to each of the containers and left them to oviposit for 7 days. Adults were then removed and the number of laid eggs was counted. After 25 days, containers were checked daily for emerged bruchids for a period of 75 days. Newly emerged beetles were transferred singly in Eppendorf tubes, frozen at $-80{ }^{\circ} \mathrm{C}$ for $10 \mathrm{~min}$ and immediately weighted. Acanthoscelides obtectus sex was determined by dissecting the genitalia.

Measurements of performance for males and females within each container included the following parameters: sex, days until adult emergence, adult weight and the percentage of emergence (number of emerged adults/ number of eggs). The average seed weight was also measured. Data were analysed with generalised linear mixed effects models. With regard to the experimental design, the mixed-effect model (i.e. a variance components model) employed accounted for the hierarchical nature of the data by assuming a common positive correlation between introduction outcomes for beetles within the same container but a zero correlation between performance of beetles in different containers. Details on the statistics are given in the Supplementary Materials.

\section{Protein extraction, SDS-PAGE and immunoblot analyses}

Thirty seeds of each bean genotype were ground to flour. Total seed proteins were extracted using 20 volumes of phosphate-buffered saline (10 $\mathrm{mM} \mathrm{KHPO}_{4}, 150 \mathrm{mM} \mathrm{NaCl}$, $\mathrm{pH}$ 7.4) for $30 \mathrm{~min}$ at room temperature and recovered in the supernatant after 5 min centrifugation at $10,000 \times g$. Protein extracts were heat denatured under reducing conditions (20 mM Tris- $\mathrm{HCl}, \mathrm{pH} 8.6$, containing $1 \%$ SDS, $8.3 \%$ glycerol and $0.5 \% \beta$-mercaptoethanol) and then separated on $15 \%$ SDS/PAGE (sodium dodecyl sulphatepolyacrylamide gel electrophoresis), as described by Bollini and Chrispeels (1978). Gels were stained with Coomassie Brilliant blue or blotted onto a Hybond-C Extra membrane (GE Healthcare) as in Ceriotti et al. (1989).

Immunoblot analyses were performed using rabbit antibodies raised against the following APA proteins from P. vulgaris $(\mathrm{Pv})$ or P. lunatus (Pl): Arc-3 (PvArc3), recombinant $\alpha \mathrm{AI}(\mathrm{Pv} \alpha \mathrm{AI})$, recombinant Lima bean lectin (PILBL), recombinant $P$. lunatus ARL (PlARL) (Ceriotti et al. 1989; Sparvoli et al. 1998, 2001).

For immunoblot analyses, antibodies raised against recombinant proteins were diluted as follows: 1:1,000 PIARL and PILBL, 1:500 PvaAI. In the case of PvArc3, the immune serum $(70 \mu \mathrm{l})$ was preincubated overnight with $630 \mu \mathrm{l}$ of a total seed extract from the Arc-null cultivar Taylor's Horticultural to reduce unspecific cross reactivity with glycoproteins (Sparvoli and Bollini 1998). As secondary antibodies, anti-rabbit IRDye 680 infrared antibodies diluted $1: 15,000$ according to the manufacturer's protocol (LI-COR Biosciences) were used and cross-reacting polypeptides were detected with a scanner at 680 nm (Starion, FLA-9000, Fujifilm, Tokyo, Japan). 
Two-dimensional gel electrophoresis and liquidchromatography tandem mass spectrometry (LC-MS/MS)

Total seed proteins were extracted in phosphate-buffered saline as described above. Isoelectric focusing was performed on $7 \mathrm{~cm}$ linear IPG strips, pH 3-10 (GE Healthcare, Milan, Italy). Strips were rehydrated overnight in a solution consisting of $9 \mathrm{M}$ urea, $2 \%$ CHAPS, $2 \%$ IPG buffer $\mathrm{pH}$ 3-10 (GE Healthcare, Milan, Italy), $65 \mathrm{mM}$ of 1,4-dithiothreitol (DTT) and containing $50 \mu \mathrm{g}$ of the protein sample from seed extracts (conveniently diluted to bring $\mathrm{NaCl}$ final concentration to $30 \mathrm{mM}$ ). The focusing was performed at $6,500 \mathrm{~V} / \mathrm{h}$, with a maximum of $3,000 \mathrm{~V}$ at $20^{\circ} \mathrm{C}$ using the Multiphor II electrophoresis unit (GE Healthcare, Milan, Italy). Prior to the second dimensional analysis, IPG strips were incubated in equilibration buffer $(375 \mathrm{mM}$ Tris- $\mathrm{HCl}$, $\mathrm{pH}$ 8.8, $6 \mathrm{M}$ urea, $2 \% \mathrm{SDS}, 20 \%$ glycerol) in the presence of $65 \mathrm{mM}$ 1,4-dithiothreitol (DTT). Strips were then incubated with the equilibration buffer containing $243 \mathrm{mM}$ iodoacetamide for $10 \mathrm{~min}$. Separation of polypeptides was performed in $12 \%$ SDS-PAGE gels using a miniPROTEAN II cell (BioRad, Hercules, CA, USA). Gels were stained with Coomassie brilliant Blue and protein polypeptides excised from 2D gels by modified Gilson pipette tips. Polypeptides were transferred to sterilised Eppendorf tubes and stored in $20 \%$ ethanol at $4{ }^{\circ} \mathrm{C}$ until use.

Polypeptides were digested with trypsin and protein identification was performed using LC-MS/MS. Trypsin digestion, mass spectrometry and protein identification were carried out by the Proteomics and Mass Spectrometry Core Facility (PMSCF) of the University of Bern, Switzerland (http://www.pmscf.dkf.unibe.ch/content/services). Fragment spectra from LC-MS/MS analysis were interpreted using the PHENYX software (operated by GeneBio, Geneva, Switzerland) against the Uniprot-Swiss-Prot protein database (UniProtKB, release 2010_12 of 30.11.2010) (http://www.uniprot.org) and uniprotKB_TREMBL (release 2011_02 of 08.02.2011). Peptide match score summation (PMSS) index was used as a semi quantitative peptide abundance indicator. This indicator summed all identification scores of peptides, which identify the same protein and weighted the scores according to their identification quality (Heller et al. 2007; Stalder et al. 2008).

cDNA isolation, sequencing and bioinformatic analysis

Total RNA was isolated, as described by van Tunen et al. (1988), from cotyledons of developing seeds in green pods harvested 20 days after pollination. Approximately $2 \mu \mathrm{g}$ of RNA were treated with DNase using the TURBO DNAfree $^{\mathrm{TM}}$ Kit (Applied Biosystems, Foster City, CA, USA) according to the manufacturer instructions. cDNA was produced using $0.5 \mu \mathrm{g}$ of DNase treated RNA with the SuperScript ${ }^{\mathrm{TM}}$ First-Strand Synthesis System for RT-PCR (Invitrogen, Carlsbad, CA, USA). For the reverse transcription reaction, the kit Oligo(dT)12-18 primers were used. APA cDNAs were amplified by PCR using the P1 and P2 primers (5'-GGCTCTGAGTCTAGAGGATRTKG TTGAGG-3' and 5'-CCATCGATAGCATGGCTTCCTCC AASTT-3', respectively) (Mirkov et al. 1994) and the GoTaq $^{\circledR}$ Green Master Mix (Promega, Madison, WI, USA). Cycling conditions were as follows: 6 cycles of denaturation at $94{ }^{\circ} \mathrm{C}$ for $1 \mathrm{~min} 30 \mathrm{~s}$, annealing at $53{ }^{\circ} \mathrm{C}$ for $1 \mathrm{~min}$, elongation at $72{ }^{\circ} \mathrm{C} 1 \mathrm{~min} 30 \mathrm{~s}$, followed by 30 cycles of denaturation at $94{ }^{\circ} \mathrm{C}$ for $40 \mathrm{~s}$, annealing at $65{ }^{\circ} \mathrm{C}$ for $45 \mathrm{~s}$, elongation at $72{ }^{\circ} \mathrm{C} 1 \mathrm{~min} 30 \mathrm{~s}$. The first 6 cycles take into account the primer pairing without the "tails", while for the next 33 cycles, conditions were adjusted considering the pairing of the whole primers. A final elongation step at $72{ }^{\circ} \mathrm{C}$ for $7 \mathrm{~min}$ was performed. The PCR product was checked on $1 \%$ agarose gel stained with ethidium bromide and purified with the QIAquick Gel Extraction Kit (Qiagen, Venlo, The Netherlands). The purified PCR amplificate (broad band around 800-830 bp) was cloned into the pJET1.2 vector of the CloneJET PCR Cloning Kit (Fermentas, Burlington, Canada), according to the manufacturer protocol. Eighteen clones were randomly selected, subcultured and purified using the QIAprep Spin Miniprep Kit (Qiagen), and sent for sequencing at Macrogen (Seoul, Korea).

Sequences were analysed with the Lasergene software package (DNASTAR, Inc., Madison, Wisconsin USA). Multiple alignments of deduced amino-acid sequences were obtained with ClustalW method and the corresponding Neighbor joining (NJ) phylogenetic tree was constructed with MegAlign (Lasergene software package, DNASTAR, Inc., Madison, WI USA). GenBank IDs of sequences used to build the multiple alignment are as follows: Arc-1 (P19329), Arc-2 (P19330), Arc-4-I (CAD29134), Arc-4-II (CAD 58679), Arc-4-III (CAD58657), Arc-5a (CAA90585), Arc5b (CAA85405), Arc-5c (AAF23725), Arc-6 (CAA04960), Arc-7 (CAD28677), aAI-1 (AAA33769), aAI-2 (CAD 28676), ARL-4 (CAD28840), ARL-4-I (JQ675761), PHA-E (CAD28837), PHA-L (CAD28838), Lec-4B17 (CAD 29133). Sequences have been deposited in GenBank database under ID: HE650833 (Arc-8); HE650835 (ARL-8); HE650834 (PHA-E).

\section{Results}

Bruchid performance

Performance of bruchid beetles was tested on three different wild bean genotypes (QUES, ISA, COPSPVC1), 
which were recently collected in Mexico, and two wild bean accessions G6388 and G12949 as controls. Accession G6388 is devoid of major lectins and is susceptible to the attack of bruchid beetles (Santino et al. 1993; Sparvoli et al. 1994; Campion et al. 2009), while G12949 contains Arc-4 and has shown resistance to both bruchid species (Osborn et al. 1988; Santino et al. 1993). Results obtained from this analysis indicated that the most resistant genotype to both bruchid species was QUES, followed by G12949, while the worst was G6388 (Fig. 1; Tables 1, 2).

A total of 334 A. obtectus individuals emerged from the 25 replicates (1,000 eggs). Beetles were able to develop on all bean genotypes tested with an overall emergence rate of $33.4 \%$ (overall sex ratio: $49.4 \%$ females and $50.6 \%$ males). QUES and ISA had the lowest A. obtectus emergence rates of all bean genotypes tested (Fig. 1). The lectin-free G6388 showed the highest emergence rate and thus seemed to be the least resistant genotype for A. obtectus development. Emerging A. obtectus males had an average weight of $3.0 \pm 1.3 \mathrm{mg} \mathrm{SD}$ and females were on average $3.9 \pm 1.9 \mathrm{mg} \mathrm{SD}$. A. obtectus females were found to be significantly heavier than males (Table 2a). The heaviest beetles emerged from the lectin-free cultivar G6388 and we found no significant differences in weights of beetles emerging from QUES, ISA, COPSPVC1 and G12949 (Fig. 1; Table 2a). Males of A. obtectus emerged significantly earlier than females (Table 2a). The longest developmental times were found for beetles developing on QUES and G12949 seeds, while significantly shorter times were needed to emerge from ISA, G6388 and COPSPVC1 seeds (Fig. 1; Table 2a).

Zabrotes subfasciatus was able to develop on all genotypes tested, but with only one female emerging from
QUES (Fig. 1). Therefore, QUES was not included in data analysis of days until beetles' emergence and beetles' weights. Four-hundred and fifty-eight $Z$. subfasciatus adults emerged from a total of 737 eggs. Overall emergence was $62.1 \%$ (overall sex ratio: $51.5 \%$ males, $48.5 \%$ females). The lowest emergence rates were observed for QUES and G12949; emergence rates from G6388, ISA and COPSPVC1 were significantly higher than those from QUES (Fig. 1; Table 2b). Emerging Z. subfasciatus females were significantly heavier than males (males: $2.0 \pm 0.3 \mathrm{mg}$ SD, females: $3.0 \pm 0.69 \mathrm{mg} \mathrm{SD}$ ). Beetles emerging from the lectin-free G6388 were heavier than beetles emerging from ISA and G12949, while there were no differences in weights of emerging Z. subfasciatus between COPSPVC1 and G6388 (Fig. 1; Table 2b). Female and male $Z$. subfasciatus needed approximately the same amount of time for their development (36 days \pm 5.9 $\mathrm{SD}$ and 36 days $\pm 6.3 \mathrm{SD}$, respectively). Only one adult female developed on QUES seeds and it emerged after 40 days. Since no other beetles were able to develop on this genotype, it was not possible to make an estimation of their average developmental time.

SDS-PAGE and immunoblot analysis of QUES seed proteins

From data reported above, the QUES and G12949 genotypes were the most resistant to the bruchid beetles tested, since they showed the lowest percentage of adult emergence and the longest developmental times for both species (Fig. 1). Bruchid resistance of G12949 has been associated to presence of Arc-4 (Schoonhoven et al. 1983; Cardona et al. 1989; Hartweck et al. 1997). In light of these data, the

Table 1 Means of percentage emergence (\%E) and days to adult emergence (DAE) of A. obtectus and Z. subfasciatus infested seeds of wild bean QUES, ISA, COPSPVC1, and the lectin-free G6388 and the Arc-4 containing G12949

\begin{tabular}{|c|c|c|c|c|c|c|c|c|c|c|}
\hline \multirow[t]{3}{*}{ GENOTYPE } & \multicolumn{5}{|l|}{ A. obtectus } & \multicolumn{5}{|c|}{ Z. subfasciatus } \\
\hline & \multirow[t]{2}{*}{$\begin{array}{l}\text { Of adults } \\
\text { emerged }^{\mathrm{a}}\end{array}$} & \multirow[t]{2}{*}{$\begin{array}{l}\% \mathrm{E}^{\mathrm{a}} \\
( \pm \mathrm{SD})\end{array}$} & \multirow[t]{2}{*}{$\begin{array}{l}\text { DAE } \\
( \pm \mathrm{SD})\end{array}$} & \multicolumn{2}{|c|}{$\begin{array}{l}\text { Mean weight }(\mathrm{mg}) \\
( \pm \mathrm{SD})\end{array}$} & \multirow[t]{2}{*}{$\begin{array}{l}\text { Of adults } \\
\text { emerged }^{\mathrm{a}}\end{array}$} & \multirow[t]{2}{*}{$\begin{array}{l}\% \mathrm{E}^{\mathrm{b}} \\
( \pm \mathrm{SD})\end{array}$} & \multirow[t]{2}{*}{$\begin{array}{l}\mathrm{DAE} \\
( \pm \mathrm{SD})\end{array}$} & \multicolumn{2}{|c|}{$\begin{array}{l}\text { Mean weight }(\mathrm{mg}) \\
( \pm \mathrm{SD})\end{array}$} \\
\hline & & & & Females & Males & & & & Females & Males \\
\hline QUES & 33 & $16.5 \pm 3.4$ & $43.0 \pm 6.5$ & $2.8 \pm 1.1$ & $3.3 \pm 1.3$ & 1 & $1.4 \pm 3.2$ & 40 & 2.5 & NA \\
\hline G12949 & 52 & $27.0 \pm 5.7$ & $48.5 \pm 5.5$ & $3.2 \pm 1.3$ & $2.8 \pm 0.9$ & 15 & $9.3 \pm 6.2$ & $60.8 \pm 8.0$ & $2.0 \pm 0.56$ & $1.5 \pm 0.28$ \\
\hline ISA & 45 & $22.5 \pm 9.4$ & $37.8 \pm 2.6$ & $3.3 \pm 1.6$ & $3.3 \pm 1.4$ & 37 & $10.8 \pm 3.9$ & $45.9 \pm 4.9$ & $2.9 \pm 0.51$ & $1.9 \pm 0.32$ \\
\hline COPSPVC1 & 65 & $32.5 \pm 5.0$ & $32.7 \pm 2.6$ & $3.1 \pm 1.5$ & $2.4 \pm 1.1$ & 66 & $69.0 \pm 7.9$ & $34.3 \pm 2.5$ & $3.1 \pm 0.51$ & $2.0 \pm 0.26$ \\
\hline G6388 & 139 & $69.5 \pm 7.6$ & $33.0 \pm 2.0$ & $5.8 \pm 1.9$ & $4.6 \pm 1.5$ & 340 & $84.0 \pm 3.6$ & $34.6 \pm 2.4$ & $3.1 \pm 0.70$ & $2.1 \pm 0.28$ \\
\hline
\end{tabular}

$S D$ standard deviation

a Percentage of A. obtectus emergence was calculated by dividing the number of emerged beetles through the number of eggs per container (eggs: $N=40$, replicates: $N=5$ )

${ }^{\mathrm{b}}$ Percentage of $Z$. subfasciatus emergence was calculated by dividing the number of emerged adults through the counted number of eggs per container (replicates: $N=5$ ) 
Table 2 Parameter estimates (estimate and $95 \%$ confidence interval) for different factors influencing the emergence rate, weight, and developmental time of A. obtectus (a) and Z. subfasciatus (b)

\begin{tabular}{|c|c|c|c|c|c|c|}
\hline \multirow[t]{2}{*}{ Effect } & \multicolumn{2}{|c|}{ Emergence rate } & \multicolumn{2}{|c|}{ Adult weight } & \multicolumn{2}{|c|}{ days until emergence } \\
\hline & Estimate & $95 \% \mathrm{CI}$ & Estimate & $95 \% \mathrm{CI}$ & Estimate & $95 \% \mathrm{CI}$ \\
\hline \multicolumn{7}{|l|}{ (a) A. obtectus } \\
\hline Sex: males versus females & NA & NA & $-0.67 *$ & {$[-0.99,-0.35]$} & $-0.19 *$ & {$[-0.26,-0.12]$} \\
\hline Seed size & - & {$[-,-]$} & - & {$[-,-]$} & - & {$[-,-]$} \\
\hline Genotype: ISA versus QUES & 0.38 & {$[-0.11,0.88]$} & 0.14 & {$[-0.57,0.84]$} & $-0.47 *$ & {$[-0.63,-0.31]$} \\
\hline Genotype: COPSPVC1 versus QUES & $0.87 *$ & {$[0.39,1.34]$} & -0.36 & {$[-1.02,0.3]$} & $-1.2 *$ & {$[-1.37,-1.03]$} \\
\hline Genotype: G12949 vs. QUES & $0.58 *$ & {$[0.09,1.06]$} & -0.1 & {$[-0.79,0.58]$} & $0.29 *$ & {$[0.15,0.43]$} \\
\hline \multicolumn{7}{|l|}{ (b) Z. subfasciatus } \\
\hline Sex males versus females & NA & NA & $-1.01 *$ & {$[-1.1,-0.91]$} & - & {$[-,-]$} \\
\hline Seed size & - & {$[-,-]$} & -0.06 & {$[-0.13,0.01]$} & -0.065 & {$[-0.135,0.005]$} \\
\hline Genotype: ISA versus G6388 & NA & NA & $-0.29 *$ & {$[-0.54,-0.04]$} & $1.13 *$ & {$[0.91,1.36]$} \\
\hline Genotype: G12949 versus G6388 & NA & NA & $-0.93 *$ & {$[-1.23,-0.62]$} & $1.82 *$ & {$[1.62,2.02]$} \\
\hline Genotype: COPSPVC1 versus G6388 & NA & NA & -0.08 & {$[-0.25,0.1]$} & -0.11 & {$[-0.29,0.08]$} \\
\hline Genotype: G12949 versus QUES & 0.68 & {$[-1.43,2.79]$} & NA & NA & NA & NA \\
\hline Genotype: G6388 versus QUES & $4.2^{*}$ & {$[2.15,6.26]$} & NA & NA & NA & NA \\
\hline Genotype: ISA versus QUES & $2.35 *$ & {$[0.27,4.43]$} & NA & NA & NA & NA \\
\hline Genotype: COPSPVC1 versus QUES & $3.5^{*}$ & {$[1.41,5.58]$} & NA & NA & NA & NA \\
\hline
\end{tabular}

Model selection (described in supplementary materials) was performed to obtain the best-fitting models and estimates were obtained by averaging over those models

Estimate indicates the mean of the estimated parameter of all models. Estimates with confidence intervals (95 \% CI) that do not include zero are significant and indicated by an asterisk (*). "-" indicates that these parameters were not included in the best fitting models and therefore they could not be estimated. $N A$ indicates factors that were not possible to be included in models

pattern of total seed proteins and the APA composition of seed extracts from QUES was compared with those of a selection of wild beans collected in Mexico (Table 1S).

In common bean, the most abundant lectins are represented by PHA-E (34 kDa) and PHA-L (32 kDa) glycoproteins (Bollini and Chrispeels 1978). The SDS-PAGE analysis revealed that QUES lacked major polypeptides with the electrophoretic mobility of PHA whereas it contained an abundant polypeptide of approximately $30 \mathrm{kDa}$, which was not present in the other genotypes (Fig. 2a, lane 9, black and white arrows, respectively). Arcelin-4 and Arc-5 polypeptides in the seed extracts of G12949 and G02771 are indicated with white arrows in Fig. 2a, lanes 1 and 2. Identification of $\alpha \mathrm{AI}$ polypeptides, which migrate in the range of $14-29 \mathrm{kDa}$ and normally represent a minor APA component, requires a protein blot analysis (Fig. 2, compare bars in panels a and c).

To verify whether the abundant $30 \mathrm{kDa}$ polypeptide belongs to the APA family, an immunoblot analysis was carried out with polyclonal antibodies having different specificities against APA components. Surprisingly, these analyses showed that QUES seeds contain mainly Arc and/ or ARL polypeptides and only some PHA-E, while aAI was not detected.

The identification of PHA-E, PHA-L, and other minor lectin components was done using antibodies raised against recombinant Lima bean lectin (PILBL) (Fig. 2b). Phytohemagglutinin cross-reacting polypeptides were recognised in all samples, however in QUES, only one cross-reacting polypeptide was detected and its electrophoretic mobility suggests that it might correspond to PHA-E (Fig. 2b, lane 9, arrowhead). In G12949 two major cross-reacting polypeptides were present: one migrates with an electrophoretic mobility similar to that of PHA-E, while the second one, which is the most abundant, is most likely a variant of PHA-L (Fig. 2b, lane 1, asterisk and empty dot, respectively). Detection of $\alpha$ AI polypeptides was done using an antiserum raised against recombinant $\alpha \mathrm{AI}$ (PvaAI), which also crossreacts with PHA polypeptides (Fig. 2c vertical bar and arrows). $\alpha$-Amylase inhibitor subunits were detectable in all samples but QUES (Fig. 2c, lane 9). Only one faint crossreacting polypeptide was detected in G12949 seed extract, which corresponds to one of the subunits of the aAI type 2, known to be present in this genotype (Minney et al. 1990; Lioi et al. 2003) (Fig. 2c, lane 1, white arrowhead). Arcelin and ARL polypeptides were detected using different antisera: one was raised against denatured Arc-3 extracted from G12953 seeds (PvArc3), which also recognises glycosylated proteins (Fig. 2d); the second one was raised against recombinant $P$. lunatus ARL (PlARL). The latter does not recognise glycosylated proteins (Fig. 2e). Both antisera detected the same major polypeptides: these included few 
Fig. 1 Performance of A. obtectus and Z. subfasciatus on different bean accessions, the lectin-free cultivar G6388, the Arc-4-containing cultivar G12949, and wild accessions QUES, ISA, COPSPVC1. Mean values per experimental container are shown. Emergence rate of A. obtectus was calculated by dividing the number of emerged beetles by the number of eggs per container (eggs: $N=40$, containers: $N=5$ ). Emergence rate of $Z$. subfasciatus was calculated by dividing the number of emerged adults by the number of eggs laid per container (containers: $N=5$ ). Numbers in the top indicates the total beetles emerged
A. obtectus
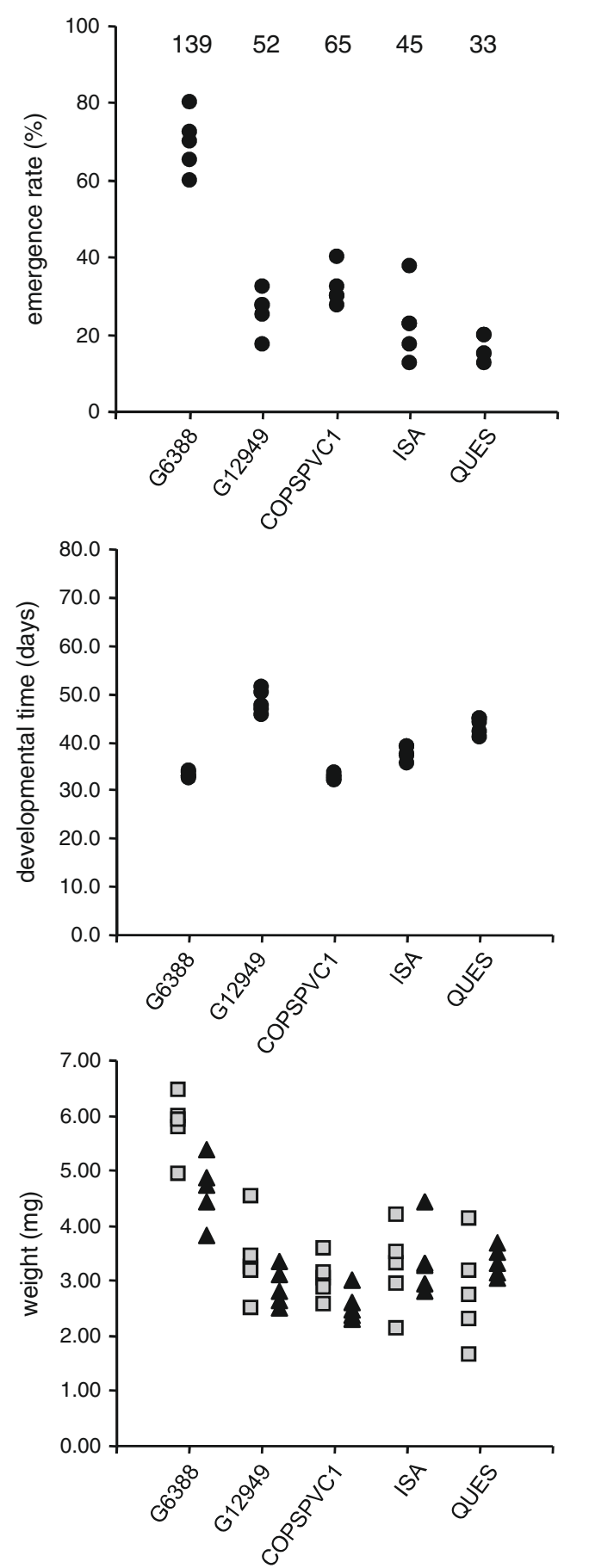

Z. subfasciatus
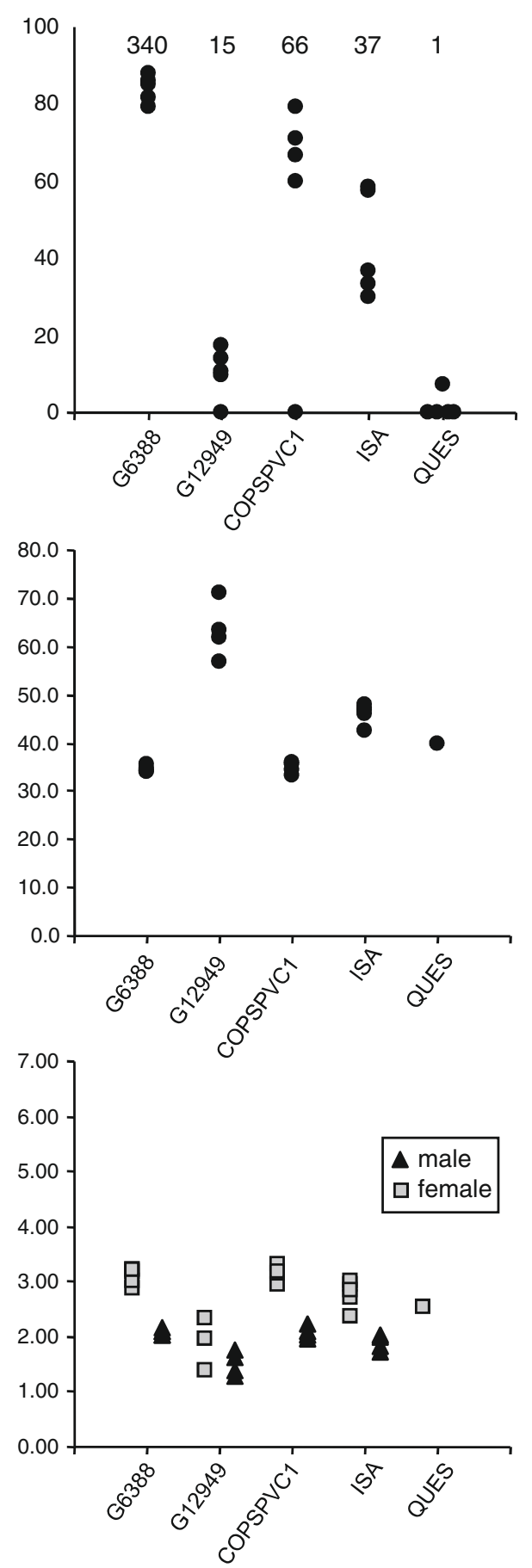

bean accession

strongly cross-reacting polypeptides corresponding to Arc and ARL proteins (Fig. 2d, e white arrows) and many less strongly reacting proteins corresponding to PHAs, minor lectins and other undescribed minor lectin-related proteins. Furthermore, the anti PvArc3-antiserum also faintly recognised some glycosylated proteins, such as phaseolin polypeptides (Fig. 2d, dotted bar).

As expected, both antisera recognised Arc polypeptides in G12949 (Arc-4) and G02771 (Arc-5) seed extracts and strongly reacted with the major $30 \mathrm{kDa}$ polypeptide present 
Fig. 2 SDS-PAGE (a) and protein blot analyses $(\mathbf{b}-\mathbf{e})$ of different $P$. vulgaris genotypes. Lanes: 1, 2 control Arc containing genotypes G12949 and G02771 (Arc-4 and Arc-5, respectively), 3 Pinto cv., 4 San Lanzano cv., 5 COPSPVC1, 6 COP1 black, 7 POC2, 8 ISA; 9 QUES, 10 VUL, 11 DMSP, 12 TEM, 13 JBSS, 14 FENCE, 15 CVC4, 16 PIL2. MW molecular weight marker. b-e: proteins were immunodetected with antibodies raised against PILBL (b), PvaAI (c), PIARL (d), PvArc3 (e), respectively. Black arrows indicate PHA-E and PHA-L and minor lectins; white arrows indicate Arc and ARL polypeptides; vertical and dotted bars indicate $\alpha \mathrm{AI}$ and phaseolin polypeptides, respectively; asterisk and circle indicate PHA-E and PHA-L cross-reacting polypetides, respectively, in G12949; black arrowhead indicates crossreacting PHA-E in QUES; white arrowhead indicates $\alpha \mathrm{AI}$ crossreacting polypeptides G12949
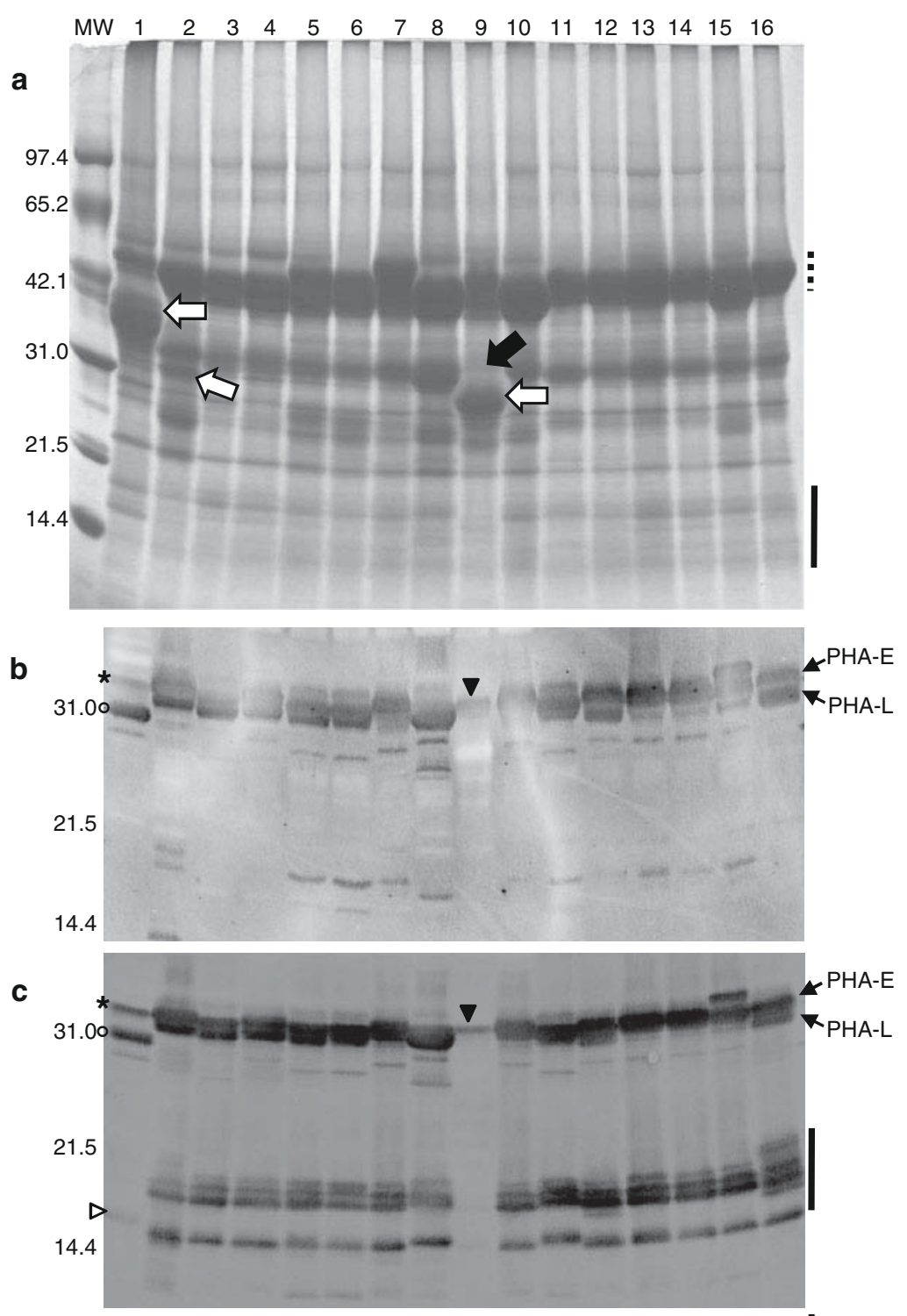

d
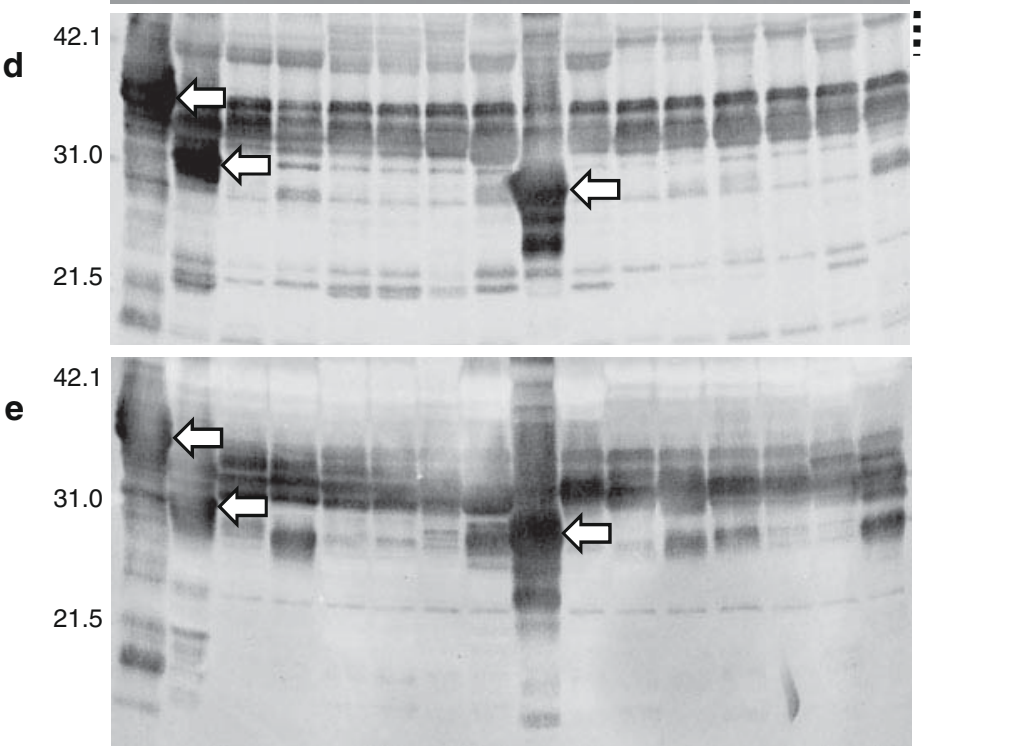
in QUES, thus indicating that it belongs to the Arc or ARL group of APA components.

Two-dimensional gel electrophoresis and mass spectrometry analysis of QUES proteins

To confirm and better characterize the $30 \mathrm{kDa}$ polypeptide, as well as other putative APA components present in QUES seeds, a two-dimensional gel electrophoresis (2DE) coupled to LC-MS/MS analysis was performed. Since phaseolin is a very abundant seed storage protein (see Fig. 2a, lane 9) and may interfere in the analysis, QUES seed extract was acidified prior to the 2DE and phaseolin removed by centrifugation (Bollini and Chrispeels 1978). After separation of proteins on a 2D gel, the most abundant polypeptides, together with those migrating with an electrophoretic mobility in the range of that observed for APA crossreacting polypeptides (between 22 and $36 \mathrm{kDa}$ ), were cut out of the gel and analysed by mass spectrometry (Fig. 3a, open circles). Results, reported in Table 3 (see Table $2 \mathrm{~S}$ for full proteomic data), confirmed immunological data. All selected polypeptides matched APA protein sequences and could be grouped into three categories: true lectins, Arc and ARL proteins. As expected, no $\alpha \mathrm{AI}$ or aAI-like (AIL) polypeptides were detected. Moreover, the best matches obtained were with APA proteins coded by APA genes from G12949 (Table 3, asterisks). Two types of lectins could be identified: an ancestral lectin, similar to Lec-4B17 (Table 3 polypeptides a1, a2, a11 corresponding to polypeptides 1, 2, 11 in Fig. 3a) and a PHA-E (Table 3 polypeptides a3, a4, a7, a17 corresponding polypeptides 3 , 4, 7, 17 in Fig. 3a). Many polypeptides, some of which were also the most abundant ones, matched Arc polypeptides, mainly similar to Arc-4-I and Arc-4-II (Table 3 polypeptides a5, a6, a8, a10, a12, a13 corresponding to polypeptides 5, 6, 8, 10, 12, 13 in Fig. 2a). Finally, two minor polypeptides corresponded to the ARL-4 (Table 3 polypeptides a14, a16 corresponding to polypeptides 14, 16 in Fig. 3a).

Identification of genes coding for QUES APA proteins

To confirm which type of APA proteins are synthesised in QUES seeds, total RNA was isolated from developing cotyledons and APA cDNAs prepared by RT-PCR using P1 and P2 primers as described by several authors (Mirkov et al. 1994; Sparvoli et al. 2001; Lioi et al. 2003, 2007). Sequencing and BLASTn analysis of 18 randomly selected clones showed that they fall into three different types of $A P A$ sequences: PHA-E (7 clones), Arc (8 clones) and ARL ( 3 clones), the last two types were named Arc- 8 and ARL8 , respectively. The phylogenetic tree obtained from the multiple alignment of the deduced amino-acid sequences of
QUES APA genes together with those of representative APA proteins showed that Arc- 8 and ARL- 8 clustered with Arc-4-I and Arc-4-II, and with ARL-4 and ARL4-I (average similarity 72 and $74 \%$, respectively) (Fig. 4), thus confirming data obtained from the proteomic analysis and indicating a strong relationship between QUES and G12949 APA loci (Table 4). Deduced amino-acid sequences of mature (without signal peptide) Arc-8, ARL-8 and PHA-E, were further analysed for the presence of putative glycosylation sites, molecular weight and isoelectric point and data are in agreement with those obtained with the proteomic analyses. In fact, the most abundant PHA-E polypeptides (Fig. 3a, polypeptides 3, 4, 7) have the most acidic pI among APA proteins and their sizes are 30 and $33 \mathrm{kDa}$, which should correspond to PHA-E isoforms bearing one or two glycan side-chains (each glycan chain contributes for $\sim 2 \mathrm{kDa}$ ). Similarly, Arc matching polypeptides (polypeptides $5,6,8,10,12,13$ ) have slightly less acidic pIs and molecular weights that most likely correspond to isoforms with one or no glycans. Finally, ARL polypeptides (polypeptides 14 and 16) have the most basic $\mathrm{pI}$ and migrate with a molecular weight that should correspond to polypeptides with a single glycan chain. For each class of APA proteins, slight differences in pIs and molecular weights should also be due to C-terminal trimming by the combined action of Asn-specific seed proteases and carboxypeptidases (Young et al. 1999).

\section{Stability of APA proteins after A. obtectus ingestion}

To gain more information on the protective role of APA components against bruchid larvae, the protein composition of A. obtectus faeces (frass) left inside the infested QUES, G12949 and G6388 seeds after adult emergence was analysed.

The polypeptide profile of total seed protein extracts was quite different from that of proteins isolated from frass (Fig. 5, compare lanes 1, 3, 5 with lanes 2, 4, 6, respectively). A remarkable finding was that phaseolin, which is very abundant in the seed (Fig. 5, lanes 1, 3, 5 dotted line), was not detectable in any frass extracts (Fig. 5, lanes 2, 4, 6 dotted lines). In contrast, APA proteins, which are highly abundant in G12949 (Arc-4) and QUES (Arc-8) seeds (Fig. 5, vertical bars), are still present in the frass, although with slightly smaller molecular sizes. We assume that these might result from a partial proteolysis of the APA proteins (Fig. 5, black bars, compare lanes 1, 3, 5 with lanes 2, 4, 6, respectively). To confirm this hypothesis, total proteins from QUES frass extract were subjected to 2DE (Fig. 3b) coupled to LC-MS/MS analysis (Table 3; Table 2S). All polypeptides analysed corresponded to bean seed storage proteins. The most abundant polypeptides in the frass extract were represented by Arc and ARL ones (Table 3). 
Fig. 3 2D gel (pH range: $3-10$; molecular weight range: $14-67 \mathrm{kDa}$ ) of seed protein extracts from QUES extract after phaseolin precipitation (a) and from frass of QUES seeds after infestation with A. obtectus (b). Numbers refer to polypeptides which were cut from the gels and then subjected LC-MS/MS analysis. $M W$ Molecular weight marker

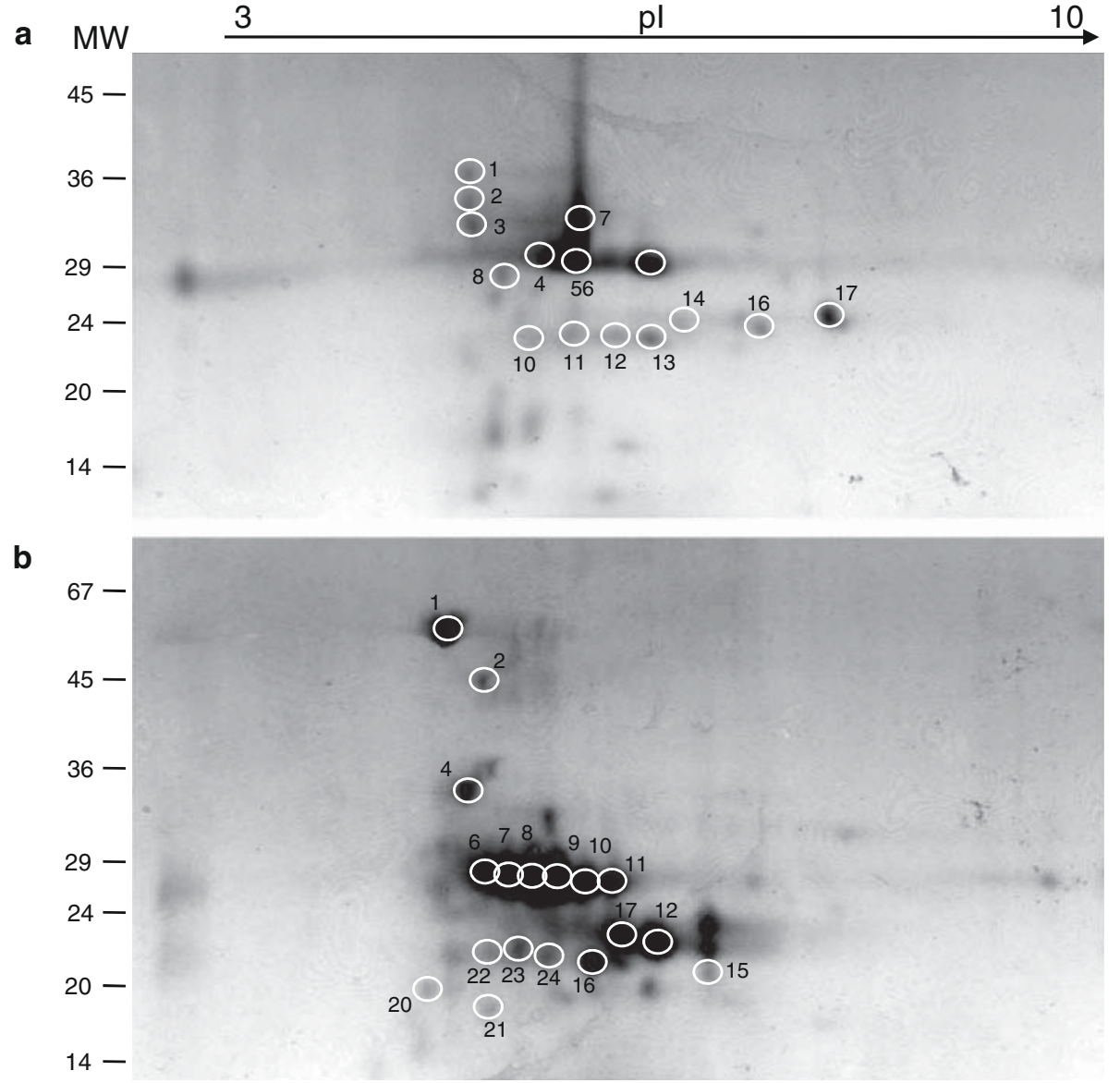

These matched 13 out of 18 polypeptides analysed, while 4 polypeptides corresponded to phaseolin subunits (Table 3, b2, b20, b21, b22 corresponding to polypeptides 2, 20, 21, 22 in Fig. 3b). Phaseolin subunits are between 43 and $50 \mathrm{kDa}$; we therefore assumed that the lower size of the residual phaseolin polypeptides in the frass (b20-b22) is the result of partial proteolytic processing. In contrast, the size of Arc and ARL polypeptides were not much different from that found in mature seeds ( $2 \mathrm{kDa}$ difference or less), thus indicating that they undergo very little digestion.

\section{Discussion}

QUES seeds contain Arc-8, a new lectin-like variant, and are resistant to bruchid attack

In this paper, we demonstrate that the seeds of the newly identified Mexican wild genotype QUES contain a new Arc variant, whose presence correlates with resistance against the bean weevil A. obtectus and the Mexican bean weevil Z. subfasciatus. Mass spectrometric analysis of QUES seed protein content as well as molecular cloning and sequencing of APA cDNAs indicates the presence of PHAE, Arc (Arc-8) and ARL (ARL-8) components. Moreover, findings reported above indicated close evolutionary relationships between QUES and G12949 APA proteins and a similar resistance against $A$. obtectus and $Z$. subfasciatus.

Results of performance experiments with A. obtectus and Z. subfasciatus provided evidence that QUES seeds have insecticidal activity against both bruchid species. Resistance to beetle infestation was expressed in significantly lower emergence rates (16.5 and $1 \%$ in A. obtectus and $Z$. subfasciatus, respectively), delayed adult emergence (44 DAE for A. obtectus and only one adult emerged after 40 days for $Z$. subfasciatus) and less heavy females emerging compared to the other genotypes we tested (G12949, ISA, COPSPVC1 and G6388).

Depending on bruchid species and Arc variant, it has been demonstrated that different levels of bean resistance to beetle infestation are expressed (Cardona et al. 1990; Dobie et al. 1990; Kornegay and Cardona 1991; Kornegay et al. 1993; Santino et al. 1993; Blair et al. 2010). For example, the highest level of resistance to $Z$. subfasciatus was found in $P$. vulgaris accessions containing Arc-5, followed by accessions with Arc-4, Arc-1 and Arc-2, while Arc-3 exhibited only moderate resistance (Cardona et al. 1990; Dobie et al. 1990; Kornegay et al. 1993). Currently, only Arc-4 containing wild genotypes have been reported to be resistant to both bruchid species (Schoonhoven et al. 
Table 3 List of 2DE-based identified polypeptides by LC-MS/MS analysis from (a) QUES seed extracts (a1 to a17) or (b) QUES seeds frass of A. obtectus (b1 to b24)

\begin{tabular}{|c|c|c|c|c|c|c|}
\hline Polypeptide $\left(n^{\circ}\right)$ & Accession $\left(n^{\mathrm{o}}\right)^{\mathrm{a}}$ & Protein identity & $\mathrm{PMSS}^{\mathrm{b}}$ & $\% \mathrm{Seq} \operatorname{Cov}^{\mathrm{c}}$ & $\mathrm{Mr}(\mathrm{Da})$ expected $^{\mathrm{d}}$ & PI expected ${ }^{e}$ \\
\hline a1 & Q8RVX5 & Lec4-B17 ${ }^{\mathrm{f}}$ & 612.7 & 59 & $29,569.23$ & 4.9 \\
\hline $\mathrm{a} 2$ & Q8RVX5 & Lec4-B17 ${ }^{\mathrm{f}}$ & 867.4 & 65 & $29,569.23$ & 4.9 \\
\hline a3 & Q8RVH3 & PHA-E ${ }^{\mathrm{f}}$ & $1,256.4$ & 76 & $27,586.87$ & 4.9 \\
\hline $\mathrm{a} 4$ & P05088 & PHA-E & 471.4 & 59 & $27,548.87$ & 5.2 \\
\hline a5 & Q8RVY3 & Arc-4-II ${ }^{\mathrm{f}}$ & 119.7 & 9 & $27,889.12$ & 7.2 \\
\hline a6 & Q41116 & Arc-5-b & 190.4 & 5 & $29,266.86$ & 7.0 \\
\hline a7 & Q8RVH3 & PHA-E ${ }^{\mathrm{f}}$ & 392.8 & 66 & $27,586.87$ & 4.9 \\
\hline a8 & Q8RVY3 & Arc-4-II ${ }^{\mathrm{f}}$ & 52.0 & 9 & $27,889.12$ & 7.2 \\
\hline a10 & Q8GU26 & Arc-4-IIII & 58.1 & 9 & $27,267.56$ & 9.1 \\
\hline a11 & Q8RVX5 & Lec4-B17 & 59.4 & 17 & $29,569.23$ & 4.9 \\
\hline a12 & Q8RVX4 & Arc- $4-\mathrm{I}^{\mathrm{f}}$ & 54.0 & 8 & $27,164.19$ & 6.1 \\
\hline a13 & Q8RVX4 & Arc-4-I ${ }^{\mathrm{f}}$ & 80.3 & 8 & $27,164.19$ & 6.1 \\
\hline a14 & Q8RVX7 & ARL $-4^{\text {f }}$ & 108.6 & 26 & $26,487.49$ & 5.7 \\
\hline a16 & Q8RVX7 & ARL $-4^{\text {f }}$ & 19.2 & 12 & $26,487.49$ & 5.7 \\
\hline a17 & P05088 & PHA-E & 153.0 & 34 & $27,548.87$ & 5.2 \\
\hline b1 & Q8RVY3 & Arc-4-II ${ }^{\mathrm{f}}$ & 33.2 & 9 & $27,889.12$ & 7.2 \\
\hline b2 & P07219 & Phaseolin, $\alpha$-type & 335.8 & 75 & $49,271.19$ & 5.3 \\
\hline b4 & Q8RVX5 & Lec4-B17 ${ }^{\mathrm{f}}$ & 87.1 & 30 & $29,569.23$ & 4.9 \\
\hline b6 & Q8RVY3 & Arc-4-II ${ }^{\mathrm{f}}$ & 164.6 & 9 & $27,889.12$ & 7.1 \\
\hline b7 & Q8RVY3 & Arc-4-II ${ }^{\mathrm{f}}$ & 147.4 & 12 & $27,889.12$ & 7.1 \\
\hline b8 & Q8RVY3 & Arc-4-II ${ }^{\mathrm{f}}$ & 157.9 & 9 & $27,889.12$ & 7.1 \\
\hline b9 & Q41116 & Arc-5-b & 175.4 & 5 & $29,266.86$ & 7.0 \\
\hline b10 & Q41116 & Arc-5-b & 214 & 5 & $29,266.86$ & 7.0 \\
\hline b11 & Q41116 & Arc-5-b & 206.4 & 5 & $27,889.12$ & 7.0 \\
\hline b12 & Q8RVX7 & ARL $-4^{\text {f }}$ & 771.4 & 28 & $26,487.49$ & 5.7 \\
\hline b15 & Q8RVX7 & ARL $-4^{\mathrm{f}}$ & 120.9 & 17 & $26,487.49$ & 5.7 \\
\hline b16 & Q8RVY3 & Arc-4-II ${ }^{\mathrm{f}}$ & 188.4 & 12 & $30,085.79$ & 7.1 \\
\hline b17 & Q8RVX7 & ARL $-4^{\mathrm{f}}$ & 295.5 & 31 & $24,276.74$ & 5.5 \\
\hline b20 & P07219 & Phaseolin, $\alpha$-type & 152.4 & 53 & $49,271.19$ & 5.3 \\
\hline $\mathrm{b} 21$ & Q9M7M4 & Mannose lectin FRIL & 275.4 & 26 & $31,102.57$ & 5.5 \\
\hline b22 & P07219 & Phaseolin, $\alpha$-type & 198.8 & 60 & $49,271.19$ & 5.3 \\
\hline b23 & Q8RVY3 & Arc-4-II ${ }^{\mathrm{f}}$ & 91.1 & 9 & $27,889.12$ & 7.2 \\
\hline b24 & Q43629 & Arc- $4^{\mathrm{f}}$ & 133.5 & 12 & $27,287.30$ & 5.9 \\
\hline
\end{tabular}

Polypeptide numbers refer to those indicated in Fig. 3a, b, respectively. For each polypeptide the best score of Peptide Match Score Summation (PMSS) is shown

${ }^{a}$ Accession number assigned by Uniprot-Swiss-Prot (release 2010_12 of 30.11.2010) and uniprotKB_tremble protein database (release_2011_02 of 08.02.2011)

${ }^{\mathrm{b}}$ Protein match score summation (PMSS): all scores from peptide spectral matches to one particular protein are added up and weighted by their identification quality. It is a measure for semi quantitative protein abundance (Heller et al. 2007; Stalder et al. 2008)

${ }^{c}$ Percentage of sequence coverage

$\mathrm{d}$ expected molecular weight

e expected isoelectric point

${ }^{\mathrm{f}}$ APA proteins identified in G12949 genotype

1983; Gatehouse et al. 1987; Dobie et al. 1990; Santino et al. 1993). Here, we show that QUES has an antibiosis effect on bruchids which is similar (A. obtectus) or even better (Z. subfasciatus) to the effect of the Arc-4 containing genotype G12949 (Fig. 1; Tables 1, 2). The phylogenetic analysis indicated that QUES APA components are very similar to those from G12949: their PHA-E are $99 \%$ identical, Arc- 8 is in the same clade with Arc-4-I and 
Fig. 4 Phylogenetic tree calculated on APA deduced amino acid sequences isolated in QUES and Arc containing genotypes. Robustness of data was evaluated by bootstrap analysis on 1,000 replicates and numbers close to the nodes represent bootstrap values. For each protein the genotype to which refers is indicated as follows: (1) to (7) Arc-1 to Arc-7, respectively; $Q$ QUES, $T$ Tendergreen. GenBank ID are reported in section "Materials and methods"

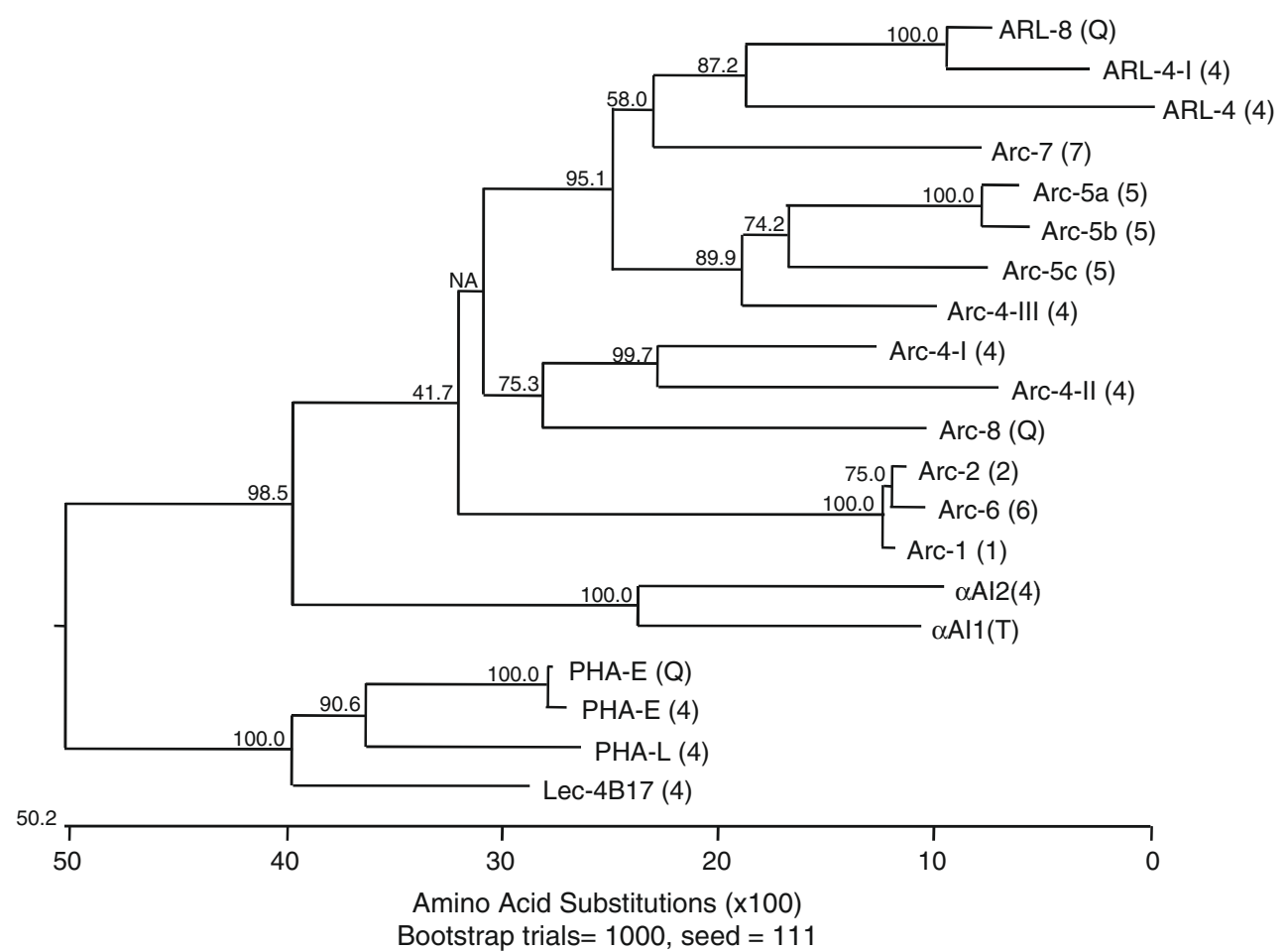

Table 4 Corresponding lectin and lectin-related sequences cloned in QUES and G12949 genotypes with respective GeneBank ID numbers

\begin{tabular}{|c|c|c|}
\hline Item & QUES & G12949 \\
\hline Arc genes & Arc-8 (HE650833) & $\begin{array}{l}\text { Arc-4-I (AJ439716) } \\
\text { Arc-4-II (AJ532486) } \\
\text { Arc-4-III (AJ519844) }\end{array}$ \\
\hline PHA/Lec genes & PHA-E (HE650834) & $\begin{array}{l}\text { PHA-E (AJ439616) } \\
\text { PHA-L (AJ439617) } \\
\text { Lec-4B17 (AJ439715) }\end{array}$ \\
\hline$\alpha \mathrm{AI}$ genes & NI & $\alpha A I-2(\mathrm{AJ} 439618)$ \\
\hline ARL genes & $A R L-8$ (HE650835) & $\begin{array}{l}A R L-4(\mathrm{AJ} 439619) \\
A R L-4-I(\mathrm{JQ} 675761)\end{array}$ \\
\hline
\end{tabular}

NI Indicates sequences not identified

Arc-4-II, and ARL components have been reported only in G12949 (Mirkov et al. 1994; Lioi et al. 2003). In light of these findings, it is not surprising that these two genotypes respond in a very similar way to the attack of $Z$. subfasciatus and A. obtectus.

Studies which have investigated performance of bruchids on $P$. vulgaris seeds showed that females are always larger than males (Howe and Currie 1964; Dendy and Credland 1991; Velten et al. 2007). In our performance experiments, males were always less heavy than females, with the only exception of $A$. obtectus females emerging from QUES seeds, which were less heavy than expected. This finding suggests that QUES may be even more

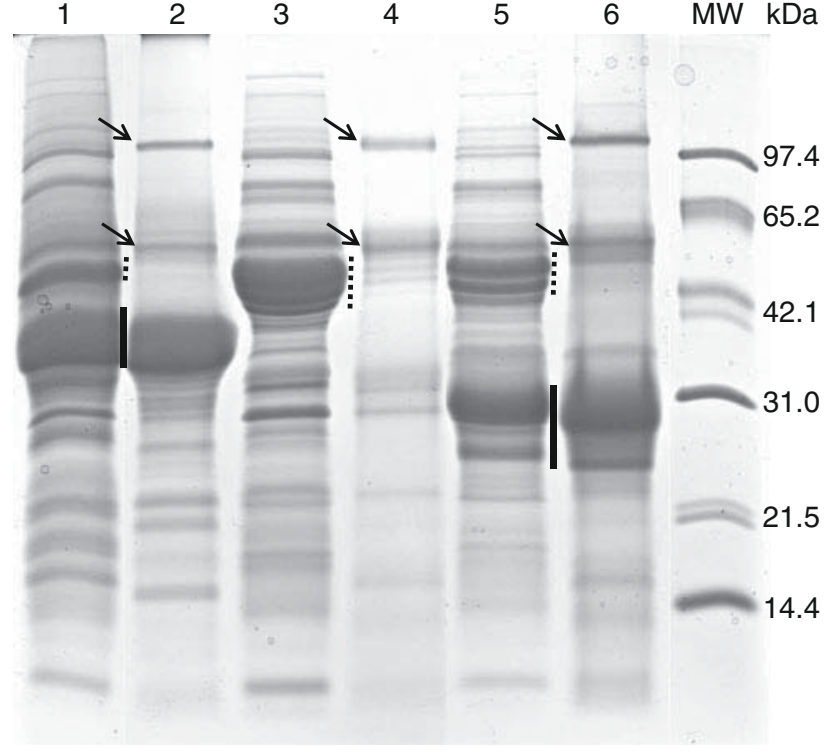

Fig. 5 SDS-PAGE of protein extracts from seeds of resistant (G12949, QUES) and susceptible (G6388) genotypes and from frass left from of A. obtectus larvae emerged from them. Lanes 1, 3, 5 seed protein extracts from seeds of G12949, G6388, QUES, respectively; lanes 2, 4, 6 frass protein extracts from infested seeds of G12949, G6388, QUES, respectively. Black bars indicate APA (Arc and ARL) polypeptides, dotted bars indicate phaseolin polypeptides, black arrows indicate specific polypeptides from A. obtectus. $M W$ molecular weight marker

effective in preventing A. obtectus infestation, since lighter females have been shown to produce fewer offspring (Velten et al. 2007). 
Arcelins are very stable proteins that survive in A. obtectus frass

Suboptimal performance of A. obtectus and Z. subfasciatus on bean seeds has always been reported to be due to the presence of Arc, which has sub-lethal effects on the developing larvae. Although our results suggest that this is the case, it cannot be excluded that other APA components may have protective effects against bruchid weevils. G6388, which is devoid of Arc and aAI and contains only reduced amounts of PHA-L (Sparvoli et al. 1994; Campion et al. 2009), was the least resistant to bruchids, since it showed the highest emergence rates for $Z$. subfasciatus and A. obtectus and the highest weights of A. obtectus adults (Fig. 1). Furthermore, Goossens et al. (2000) found, when creating transgenic tepary bean ( $P$. acutifolius) lines expressing Arc-5, that their resistance levels were lower than those of Arc-5 containing P. vulgaris accessions and suggested that resistance cannot be attributed to Arc-5 alone, but also to other factors.

The mechanisms by which arcelins confer resistance to $Z$. subfasciatus and A. obtectus are still unclear. In contrast to PHA and $\alpha \mathrm{AI}$, no specific biological activity has been determined for arcelins and only very weak agglutination activity has been reported for some of them (Hartweck et al. 1991; Fabre et al. 1998). Different hypotheses have been suggested to explain bruchid resistance conferred by arcelins. The insecticidal activity may be related to the high level of arcelins in the seed (Osborn et al. 1988). Alternatively, arcelins, which are strongly resistant to proteolysis by bean weevil larval enzymes in vitro, may simply be indigestible to beetles and lead to larval starvation (Minney et al. 1990; Goossens et al. 2000). Some research has shown that Arc-1 binds to epithelial cells of Z. subfasciatus midgut and lead to disruption of nutrient absorption (Paes et al. 2000). Moreover, it might be that arcelins act with different mechanisms towards Z. subfasciatus and A. obtectus (Minney et al. 1990).

Insect frass is a valuable source for the identification of many plant defence proteins which, as shown in Manduca sexta, readily accumulate in the insect midgut and are highly resistant to digestive proteases (Chen et al. 2007). This finding was also observed for A. obtectus larvae reared on resistant accessions of $P$. lunatus, which contain large amounts of ARL and AIL proteins in the seed (Fileppi et al. 2002). Here, we provide further evidence that resistance to proteolysis might play a major role in the mechanisms of resistance. In fact, large amounts of Arc and ARL of both QUES and G12949 seeds are excreted in the frass of A. obtectus larvae. To our knowledge, this is the first direct evidence of this behaviour in vivo and against the bean weevil, since Minney et al. (1990) arrived at a similar conclusion by performing in vitro digestion assays on purified Arc-4 using Z. subfasciatus larvae gut enzymes.
Phaseolin has been shown to be readily digestible by Z. subfasciatus larvae, and therefore, it has an important nutritional value for bruchid larvae (Minney et al. 1990). Hartweck et al. (1997) proposed that the increased resistance in phaseolin-null seeds compared to phaseolin-containing seeds might be not only due to a compensation of the absence of phaseolin by Arc but also due to the general absence of phaseolin as an easily digestible protein. Thus, the prolonged development and low emergence rates of Z. subfasciatus and A. obtectus, when raised on QUES and G12949 seeds, could be explained by the inability of larvae to digest Arc and ARL proteins, which would lead to starvation of larvae due to an insufficient supply with essential amino acids.

Biological activities have been recognised also for other APA components present either in Arc containing genotypes or in other Phaseolus species. This is the case of aAI2, found in Arc-4 and Arc-3 containing genotypes, which is able to inhibit Z. subfasciatus $\alpha$-amylase, or of AIL sequences for which an $\alpha \mathrm{AI}$ activity, against human saliva $\alpha$-amylase has been reported as well (Grossi de $\mathrm{Sa}$ et al. 1997; Lioi et al. 2007). The other types of APA proteins, which may play an important role in A. obtectus resistance, are Arc-like proteins. These types of proteins have been reported only in species ( $P$. acutifolius and $P$. lunatus) and genotypes (G12949 and QUES, as reported in this paper), which are known to be resistant to A. obtectus (Dobie et al. 1990; Mbogo et al. 2009). Moreover, besides APA proteins other factors, genetically closely linked to the APA locus may be involved in bruchid antibiosis (Goossens et al. 2000; Zambre et al. 2005).

In conclusion, we show that resistance of $P$. vulgaris seeds is clearly associated with the presence of Arc and ARL proteins (which for A. obtectus are clearly of the Arc4 and Arc- 8 types). However, overall the data also suggest that further studies are needed to clarify the exact mode of action of Arc and ARL proteins and, in particular, to verify if they possess any biological activity.

\section{Breeding perspectives of the resistance to A. obtectus}

While the transfer of resistance to Z. subfasciatus from wild into cultivated bean genotypes has been demonstrated to be achievable (Cardona et al. 1990), the same does not hold true for resistance to A. obtectus. The transfer was more difficult for this species, with plant resistance levels decreasing as generations progressed. To explain this type of inheritance, Kornegay and Cardona (1991) hypothesised a two-gene model. A multiple or synergistic interaction of Arc with other factors may be involved, which would have not been transferred in a crossing process. As such, a breeding approach is more likely to transfer intact resistance, but resistance can be lost if the breeding is done 
without selection pressure for the trait of interest. To this aim, development of molecular markers tightly associated to the resistance trait is highly needed. The recent work of (Blair et al. 2010), who mapped 15 microsatellites on an F2 population of 157 individuals resulting from a susceptible $\times$ resistant cross that segregated for both the Arc-1 allele and resistance to Z. subfasciatus, provided useful information in this sense. However, in the case of resistance to A. obtectus, the breeding process has been hampered by a lack of genetic tools for understanding the APA locus.

The majority of bean genotypes have a "simple" APA locus containing genes coding only for PHA and $\alpha \mathrm{AI}$ (Ishimoto et al. 1995), whose size is $<40 \mathrm{kbp}$ (www. phytozome.net/, Gbrowse P. vulgaris-v1.0 Chr04:43,994, 500.0.44,044,500). In contrast, Arc containing genotypes present clear evidence of gene duplications and, in all cases, except Arc-3 and Arc-4 containing genotypes, deletions of the region carrying the gene coding for $\alpha \mathrm{AI}$ (Lioi et al. 2003). Moreover, a detailed study of the APA locus of G12949, obtained by analysing about 50 BAC clones covering the entire locus, allowed us to estimate a locus size of approximately $500 \mathrm{Kbp}$ (Galasso et al. 2005; Sparvoli et al. 2008; Gepts et al. 2008). The presence of clusters of coding and non-coding APA sequences, large duplicated regions together with entire and many truncated retrotransposon and transposon sequences were found. The latter finding is in agreement with previous reports on the partial sequencing of the APA locus from an Arc-5 containing genotype (Kami et al. 2006). In addition, it was found that $P H A-L$ and $\alpha A I$ are present in BAC contigs, which are separated from those containing PHA-E, Arc-4-I, Arc-4-II, Arc-4-III, ARL-4 and ARL-4I genes. In the present paper it is shown that QUES APA components are very similar to those of G12949 and this may suggest similarity of the whole locus (Fig. 4; Table 4). However, no biochemical or molecular evidence was found for the presence of PHA-L, $\alpha \mathrm{AI}$ and AIL components in QUES. We hypothesise that in this genotype, a deletion occurred, involving the genomic region carrying these genes, as already has been reported for other Arc containing genotypes. Therefore, most likely QUES carries an APA locus smaller than that of G12949 and this should facilitate its transfer into cultivated genotypes with concomitant maintenance and stability of the resistance trait against A. obtectus.

Acknowledgments Research was partially supported by MiPAAF with funds released by C.I.P.E (Resolution 17/2003) and by Regione Lombardia/CNR agreement, project 2 to FS; IZ was supported by the National Center of Competence in Research (NCCR), "Plant Survival". We thank Prof. Marcello Duranti and Dr. Eleonora Cominelli for critical reading of the manuscript and helpful suggestions.

\section{References}

Blair MW, Muñoz C, Buendía HF, Flower J, Bueno JM, Cardona C (2010) Genetic mapping of microsatellite markers around the arcelin bruchid resistance locus in common bean. Theor Appl Genet 121:393-402

Bollini R, Chrispeels MJ (1978) Characterization and subcellular localization of vicilin and phytohemagglutinin, the two major reserve proteins of Phaseolus vulgaris L. Planta 142:291-298

Campion B, Perrone D, Galasso I, Bollini R (2009) Common bean (Phaseolus vulgaris L.) lines devoid of major lectin proteins. Plant Breed 128:199-204

Cardona C (2004) Common beans: Latin America. In: Hodges R, Farrell G (eds) Crop post-harvest: science and technology durables, vol 2. Blackwell, Oxford, pp 145-150

Cardona C, Kornegay J (1999) Bean germplasm resources for insect resistance. In: Clement S, Quisenberry S (eds) Global plant genetic resources for insect-resistant crops. CRC Press, Boca Raton

Cardona C, Posso CE, Kornegay J, Valor J, Serrano M (1989) Antibiosis effects of wild dry bean accessions on the Mexican bean weevil and the bean weevil (Coleoptera: Bruchidae). J Econ Entomol 82:310-315

Cardona C, Kornegay J, Posso C, Morales F, Ramirez H (1990) Comparative value of four arcelin variants in the development of dry bean lines resistant to the Mexican bean weevil. Entomol Exp Appl 56:197-206

Carlini CR, Grossi-de-Sá MF (2002) Plant toxic proteins with insecticidal properties. a review on their potentialities as bioinsecticides. Toxicon 40:11515-11539

Ceriotti A, Vitale A, Bollini R (1989) Lectin-like protein accumulates as fragmentation products in bean seed protein bodies. FEBS Lett 250:157-160

Chen H, Gonzales-Vigil E, Wilkerson CG, Howe GA (2007) Stability of plant defense proteins in the gut of insect herbivores. Plant Physiol 143(4):1954-1967

Dendy J, Credland PF (1991) Development, fecundity and egg dispersion of Zabrotes subfasciatus. Entomol Exp Appl 59:9-17

Dobie P, Dendy J, Sherman C, Padgham J, Wood A, Gatehouse AMR (1990) New sources of resistance to A. obtectus (Say) and Zabrotes subfasciatus Boheman (Coleoptera: Bruchidae) in mature seeds of five species of Phaseolus. J Stored Prod Res 26(4):177-186

Fabre C, Causse H, Mourey L, Koninkx J, Rivière M, Hendriks H, Puzo G, Samama JP, Rougé P (1998) Characterization and sugar-binding properties of arcelin-1, an insecticidal lectin-like protein isolated from kidney bean (Phaseolus vulgaris L. cv. RAZ-2) seeds. Biochem J 329:551-560

Fileppi M, Sparvoli F, Bollini R (2002) Major lima bean seed storage proteins are poorly digested by bean weevil larvae. In: International conference on legume genomics and genetics: translation to crop improvement, Minneapolis-St Paul, MN, USA, 2-6 June, p 126

Galasso I, Lioi L, Lanave C, Campion B, Bollini R, Sparvoli F (2005) Identification and sequencing of a BAC clone belonging to the Phaseolus vulgaris (L.) insecticidal Arc4 lectin locus. Bean Improvement Cooperative 48, p 40

Gatehouse AMR, Dobie P, Hodges RJ, Meik J, Pusztai A, Boulter D (1987) Role of carbohydrates in insect resistance in Phaseolus vulgaris. J Insect Physiol 33(11):843-850

Gepts P, Aragão FJL, de Barros E, Blair MW, Brondani R, Broughton W, Galasso I, Hernández G, Kami J, Lariguet P, McClean P, Melotto M, Miklas P, Pauls P, Pedrosa-Harand A, Porch T, Sánchez F, Sparvoli F, Yu K (2008) Genomics of Phaseolus beans, a major source of dietary protein and micronutrient in the Tropics. In: Moore PH, Ming R (eds) Genomics of tropical crop plants. Springer, Berlin, pp 113-143 
Goossens A, Quintero C, Dillen W, De Rycke R, Valor JF, De Clercq J, Van Montagu M, Cardona C, Angenon G (2000) Analysis of bruchid resistance in the wild common bean accession G02771: no evidence for insecticidal activity of arcelin 5. J Exp Bot 51:1229-1236

Grossi de Sa MF, Mirkov TE, Ishimoto M, Colucci G, Bateman KS, Chrispeels MJ (1997) Molecular characterization of a bean alpha-amylase inhibitor that inhibits the alpha-amylase of the Mexican bean weevil Zabrotes subfasciatus. Planta 203:295-303

Hartweck LM, Osborn TC (1997) Altering protein composition by genetically removing phaseolin from common bean seeds containing arcelin or phytohemagglutinin. Theor Appl Genet 95:1012-1017

Hartweck LM, Vogelzang RD, Osborn TC (1991) Characterization and comparison of arcelin seed protein variants from common bean. Plant Physiol 97:204-211

Heller M, Schlappritzi E, Stalder D, Nuoffer J-M, Haeberli A (2007) Compositional protein analysis of high density lipoproteins in hypercholesterolemia by shotgun LC-MS/MS and probabilistic peptide scoring. Mol Cell Proteomics 6:1059-1072

Howe RW, Currie JE (1964) Some laboratory observations on the rates of development, mortality and oviposition of several species of Bruchidae breeding in stored pulses. Bull Entomol Res 55:437-477

Ishimoto M, Suzuki K, Iwanaga M, Kikuchi F, Kitamura K (1995) Variation of seed $\alpha$-amylase inhibitors in the common bean. Theor Appl Genet 90:425-429

Kami J, Poncet V, Geffroy V, Gepts P (2006) Development of four phylogenetically arrayed BAC libraries and sequence of the APA locus in Phaseolus vulgaris. Theor Appl Genet 112:987-998

Kornegay J, Cardona C (1991) Inheritance of resistance to A. obtectus in a wild common bean accession crossed to commercial bean cultivars. Euphytica 52:103-111

Kornegay J, Cardona C, Posso CE (1993) Inheritance of resistance to Mexican bean weevil in common bean, determined by bioassay and biochemical tests. Crop Sci 33:589-594

Kusolwa PM, Myers JR (2011) Seed storage proteins Arl2 and its variants from the APA locus of wild tepary bean G40199 confers resistance to A. obtectus when expressed in common beans. Afr Crop Sci J 19:255-265

Lioi L, Sparvoli F, Galasso I, Lanave C, Bollini R (2003) Lectinrelated resistance factors against bruchids evolved through a number of duplication events. Theor Appl Genet 107:814-822

Lioi L, Galasso I, Lanave C, Daminati MG, Bollini R, Sparvoli F (2007) Evolutionary analysis of the APA genes in the Phaseolus genus: wild and cultivated bean species as sources of lectinrelated resistance factors? Theor Appl Genet 115:959-970

Mbogo PK, Myers JR, Davis J (2009) Transfer of the ArcelinPhytohemmaglutinin- $\alpha$ Amylase inhibitor seed protein locus from tepary bean (Phaseolus acutifolius A. Gray) to common bean (P. vulgaris L.). Biotechnology 8:285-295

Minney BHP, Gatehouse AMR, Dobie P, Dendy J, Cardona C, Gatehouse JA (1990) Biochemical bases of seed resistance to Zabrotes subfasciatus (bean weevil) in Phaseolus vulgaris (common bean): a mechanism for arcelin toxicity. $\mathrm{J}$ Insect Physiol 36:757-767

Mirkov TE, Wahlstrom JM, Hagiwara K, Finardi-Filho F, Kjemtrup S, Chrispeels MJ (1994) Evolutionary relationships among proteins in the phytohemagglutinin-arcelin- $\alpha$-amylase inhibitor family of the common bean and its relatives. Plant Mol Biol 26:1103-1113
Myers JR, Davie J, Kean D, Nchimbi-Msolla S, Misangu R (2001) Backcross breeding to introduce Arcelin alleles into improved African bean cultivars. In: Proceedings "Bean seed workshop" Arusha, Tanzania 12-14 Jan. http://sustainableseedsystems. wsu.edu/proceedings/Myers.pdf

Nishizawa K, Teraishi M, Utsami S, Ishimoto M (2007) Assessment of the importance of $\alpha$-amylase inhibitor 2 in bruchid resistance of wild common bean. Theor Appl Genet 114:755-764

Osborn TC, Alexander DC, Sun S, Cardona C, Bliss F (1988) Insecticidal activity and lectin homology of arcelin seed protein. Science 240:207-210

Paes NS, Gerhardt IR, Coutinho MV, Yokoyama M, Santana E, Harris N, Chrispeels MJ, Grossi-de-Sá MF (2000) The effect of arcelin-1 on the structure of the midgut of bruchid larvae and immunolocalization of the arcelin protein. J Insect Physiol 46: 393-402

Santino A, Orchard J, Daminati MG, Cantoni R, Bollini R (1993) Bean (Phaseolus vulgaris L.) lectins and protection of the stored seed. In: Basu J, Kindu M, Chakrabarti P (eds) Lectins: Biology, Biochemistry, Clinical Biochemistry, vol 9. Wiley Eastern Lt., New Delhi, pp 19-26

Schoonhoven A, Cardona C, Valor J (1983) Resistance to the bean weevil and the Mexican bean weevil (Coleoptera: Bruchidae) in non-cultivated common bean accessions. J Econ Entomol 76: $1255-1259$

Sparvoli F, Bollini R (1998) Arcelin in wild bean (Phaseolus vulgaris L.) seeds: sequence of arcelin 6 shows it is a member of the arcelin 1 and 2 subfamily. Genet Res Crop Evol 45:383-388

Sparvoli F, Daminati MG, Bollini R (1994) Biochemical and molecular characterisation of a Phaseolus vulgaris mutant lacking the major lectin-related seed proteins. Ann Rep Bean Improv Coop 37:110

Sparvoli F, Lanave C, Satucci A, Bollini R, Lioi L (2001) Lectin and lectin-related proteins in lima bean (Phaseolus lunatus L.) seeds: biochemical and evolutionary studies. Plant Mol Biol 45:587597

Sparvoli F, Galasso I, Lioi L, Campion B, Nielsen E, Hernandez G, Bollini R (2008) Modulation of antinutritional components in common bean (Phaseolus vulgaris L.) seeds. In: IV International conference on legume genomics and genetics, Puerto vallarta, Mexico, 7-12 Dec, p 100

Stalder D, Haeberli A, Heller M (2008) Evaluation of reducibility of protein identification results after multidimensional human serum protein separation. Proteomics 8:414-424

van Tunen AJ, Koes RE, Spelt CE, van der Krol AR, Stuitje AR, Mol JN (1988) Cloning of the two chalcone flavanone isomerase genes from Petunia hybrida: coordinate, light-regulated and differential expression of flavonoid genes. EMBO 7:1257-1263

Velten G, Rott AS, Cardona C, Dorn S (2007) The inhibitory effect of the natural seed storage protein arcelin on the development of $A$. obtectus. J Stored Prod Res 43:550-557

Young NM, Thibault P, Watson DC, Chrispeels MJ (1999) Posttranslational processing of two alpha-amylase inhibitors and an arcelin from the common bean, Phaseolus vulgaris. FEBS Lett 446(1):203-206

Zambre M, Goossens A, Cardona C, Van Montagu M, Terryn N, Angenon G (2005) A reproducible genetic transformation system for cultivated Phaseolus acutifolius (tepary bean) and its use to assess the role of arcelins in resistance to the Mexican bean weevil. Theor Appl Genet 110(5):914-924 